\title{
The Second Generation: Heritage Language Maintenance - Native English Speakers Living in Israel - Case Study No. 3
}

\author{
Orly Kayam $\mathrm{PhD}$ \\ Wingate Academic College, Netanya, Israel \\ Doi:10.5296/jsr.v5i1.5133ＵRL: http://dx.doi.org/10.5296/jsr.v5i1.5133
}

\begin{abstract}
Heritage language maintenance faces additional challenges when native English speakers intermarry with partners from the host society. This paper, the third in a series, focuses on the family language policies, or lack thereof, of two generations of English speaking women married to Hebrew speaking Israeli men.
\end{abstract}

Key Words: Bilingualism, Heritage Language Maintenance, Family Language Policy, Sociolinguistics

\section{Introduction}

In this current study, the third in a series examining the family language policies of native English speakers living in Israel, we focused on the family language policies, or lack thereof, of two generations of English speaking women married to Hebrew speaking Israeli men.

We interviewed Dina Heller about both her birth family and her and her sister's current families regarding the role of English in their lives.

We also compare and contrast the Heller family decisions to those of the families interviewed in our previous articles (Kayam and Hirsh, 2013; Kayam, 2013).

Theoretical Background

For the past ten years, Family Language Policy has raised considerable interest and curiosity among linguists and sociolinguists in countries where the presence of ethnic minority groups live. Indeed, in a research paper carried out in the United States by Ha Lam (2011) on Raising Children bilingually in Mixed Marriages[...] it is mentioned the fact that "there are an increasing number of studies on family language policy at microlevel". In the same way, Mila Schwartz (2010), in her research paper on FLP considers this subject of study as an "[...] emerging field".

This strong interest in FLP which has been put forward in recent studies has been stirred by the presence of populations of various ethnic origins in a given place. Indeed, the increasing rate of immigration in a number of countries as is the case in the UK for example also explains this phenomenon. As is pointed out in Andrea Donakey's 2007 paper entitled: "Language Planning and Policy In Manchester": "this is leading to a rise in metropolitan 
multilingualism with more and more people in urban localities using languages other than English, or "community languages"”.

The purpose of FLP is to examine and analyze language practices through "various management techniques" (Spolsky, 2004). As mentioned in a paper by Xiao Lan Curdt-Christiansen, Associate Professor in the Department of English Language and Literature, National Institute of Education (NIE), Nanyang Technological University, Singapore, FLP "interacts with a wide range of socio-historical, political, cultural and linguistic variables and factors (Spolsky 2012; King and Fogle 2013). As such, the study of FLP not only contributes to our understanding of the processes of language shift and change, it also sheds lights on broader language policy issues at societal levels."

Method

A one-on-one interview was conducted with Dina Heller. Dina presented her family history starting with her parents' choices and then her and her sister's choices regarding family language policy and practice. Pseudonyms have been used to protect the Hellers' privacy.

\section{Dina's Parents}

Dina's mother Rita is a British born English teacher who moved to Israel in the early 1960s when she was in her 20s. In Israel she met her husband Saul, a doctor, who is a fifth generation Israeli of German extraction. They have two children, Riva born in 1965 in Jerusalem and Dina, born in 1970 in South Africa where Rita had relatives. The family did not stay in South Africa very long returning the same year to Israel. In 1979 the family relocated to Canada where both girls attended a Jewish day school. From 1980 the family lived in the United States until 1995 when Dina decided to move to Israel and Riva decided to join her. Rita and Saul still live in the States. Given how the family moved about raises the question: Which language is the heritage language? Is it English or is it Hebrew? Dina says that there was never any explicitly stated language policy, each parent spoke in his/her native tongue and the children responded in the language they were spoken to.

\section{Dina's Sister Riva}

Riva was born in Jerusalem in 1965. When the family relocated abroad in 1979 Riva was already in high school and possessed a high level of Hebrew proficiency while her English was at a much lower level. However, after completing high school and then university studies at both the undergraduate and graduate level in the United States Riva is totally bilingual.

Riva followed her sister to Israel in 1995 with no long term plans, however within two years she was married to Haim, an Israeli born man whose own parents had immigrated to Israel from Morocco. Haim is trilingual having learned French from his parents and English from a ten year sojourn in California.

Riva and Haim have two sons, 15 year old Ido and 13 year old Eden. Riva decided to speak only English at home because she believed that knowing English is a great asset in today's world. Even when Ido was diagnosed with multiple learning disabilities she was not willing to forgo the emphasis she put on English proficiency and she devoted many hours to reading 
English stories to Ido. Ido is a fluent English speaker and this ability gives him confidence and helps him cope with his academic difficulties. Eden understands spoken English but does not speak it. This does not reflect a change in Riva's belief in the importance of English but rather time constraints as much of her energy is devoted to helping Ido. Haim speaks to his sons in Hebrew. Riva and Haim speak to each other in Hebrew.

\section{Dina's family}

Dina is married to Avi who was born in Israel to parents who immigrated to Israel from Iraq. Avi speaks only Hebrew at native language level though he understands English from school and university studies and rudimentary Arabic from his parents. Dina communicates with her husband in Hebrew. Dina and Avi have two daughters: Hani born in 2003 and Hava born in 2007. Both girls were born in Israel. Dina, an English teacher like her mother, felt very strongly about speaking only English with her children. She not only saw English as a valuable tool but as a part of her culture which she wanted to share with her children, so in addition to speaking with them in English she read them stories and taught them songs and nursery rhythms from her childhood. When they were small she also took them on annual trips to the States to visit her parents.

Her commitment to an English only policy was difficult to maintain once Hani came home from kindergarten speaking Hebrew. From this point she spoke with her daughter in Hebrew and English depending on the situation. Dina explained: "As her surroundings were completely Hebrew speaking, and I spoke Hebrew with my husband and our friends, it became difficult to demand from her to speak English with me. Also, when I would speak to her in English, she would respond in Hebrew, making it difficult to carry on a conversation. At some point, it just became too confusing and difficult."

When Hava was born she tried to speak with her in English. Daily routines are conducted in English and are understood by both girls though the younger girl does not understand each word but understands what is being asked. For instance, Dina might say: "Go brush your teeth" and Hava will answer half in Hebrew "But Mommy I already" and half in English "brushmyteeth" relating to the English phrase as if it were one word. Other examples of daily interactions like "Are you hungry?" are understood but replied to in Hebrew.

Now that Hani has started studying English in school she has begun to have a greater interest in English and will come home from school and initiate conversations in English. She takes pride in her personal family connection to English. Dina's parents continue to send English books and tapes from America.

Dina hopes that the emphasis she places on the importance of English and their exposure to the English language will influence the girls. But ultimately she believes the desire to learn English will have to come from them.

\section{Discussion}

Heritage language maintenance can be viewed as a zero to ten continuum where zero represents total assimilation into the host country and total abandonment of the heritage language. This would be common in cases of people living in situations where nobody else 
speaks their heritage language. At the other end of the spectrum would be people who live in a self-imposed ghetto, speaking their own language exclusively and having little or no contact with the host society as can be seen in any large city's Chinatown and Little Italy. Participants in our case studies fall in the middle where all are bilingual to a greater or lesser degree. Among our subjects the Weiss family (Kayam, 2013) represent the strongest commitment to heritage language maintenance with both parents speaking only English to their children and providing extra English language reinforcement in the form of English speaking babysitters and classes for native English speakers. Debbie's family (Kayam and Hirsh, 2012) come next with the mother Debbie speaking only English and taking her children for extended stays in the States though that stopped as her children got older. The least committed, ironically, was Dina, an English teacher whose entire professional identity is centered on the English language, raising her children in a practically Hebrew only environment while trying to impart a rudimentary knowledge and love of English language and culture.

\section{References:}

Baker, C. (1995). A parents' and teachers guide to bilingualism. Clevendon, UK: Multilingual Matters.

Bayley, Robert \& Schecter, Sandra R. 2003. Introduction: Toward a dynamic model of language socialization. In Bayley \& Schecter (eds.), pp. 1-6.

Bradatan, C. (2013). "Born Again in a Second Language". International Herald Tribune, August 12, 2013.

Burns, Allan F. 1984. Join the circle: The folklore of Florida's children. In First citizens and other Florida folks: Essays on Florida folklife. Tallahassee: Bureau of Florida Folklife Programs, Division of Archives. Florida Department of State.

Cardozo-Freeman, Inez. 1975. Games Mexican girls play. Journal of American Folklore 88 (347), pp. 12-23.

Cho, G., \& Krashen, S. (2000). The role of voluntary factors in heritage language development: How speakers can develop the heritage language on their own. ITL: Review of Applied Linguistics, 127-140.

Ben-Rafael, E., Shohamy, E., Amar, M.H., \& Trumpet-Hecht, N. (2004). Linguistic landscape and multiculturalism: A Jewish-Arab comparative study. Tel Aviv: Tami Steinmetz Center for Peace Research.

Crystal, D. (2003). English as a global language. Cambridge University Press.

Cummins, J. (1991). Language Development and Academic Learning. In L. Malavé \& G. Duquett (Eds.), Language, culture, and cognition (pp. 161-175). Clevedon, UK: Multilingual Matters Ltd.

De Capua, A., \& Wintergerst, A. C. (2009). "Second-Generation Language Maintenance and Identity: A Case Study”. Bilingual Research Journal. 32:1, 5-24.

De Houwer, A. (2000). Children's linguistic environments: a first impression. In M. Beers, B. van den Bogaerde, G. Bol, J. de Jong, \& C. Rooijmans (Eds.), From Sound to Sentence. Studies on first language acquisition (pp. 57-68). Groningen: Centre for language and cognition.

de la Piedra, María \& Romo, Harriet D. 2003. Collaborative literacy in a Mexican immigrant 
household: The role of sibling mediators in the socialization of pre-school learners. In Bayley \& Schecter (eds.), pp. 44-61.

Döpke, S. (1992). One parent one language: An interactional approach. Philadelphia: John Benjamins.

Donakey, A. (2007). Language Planning and Policy in Manchester. A dissertation submitted to the University of Manchester for the degree of Master of Arts in the Faculty of Humanities, School of Languages, Linguistics and Cultures.

English Curriculum, (2001). Israel Ministry of Education.

Garett, P., Coupland, N., \& Williams, A. (2003). Investigating language attitudes: Social Meanings of dialect, ethnicity and performance. Cardiff, UK: University of Wales Press.

Hakuta, K., \& d' Andrea, D. (1992). "Some properties of bilingual maintenance and loss in Mexican background high school students". Applied Linguistics, 13, 72-99.

Hoff, E. (2006). "How social contexts support and shape language development". Developmental Review, 26, 55-88.

Kayam, O. (2013). "Heritage Language Maintenance among Native English Speakers Living in Israel”. Journal of Sociological Research, Vol. 4. No. 2. pp. 308-317.

Kayam, O., Hirsch, T. (2013). "Israel's English Speaking Immigrant Parents' Family Language Policy Management: Language in the Education Domain”. International Journal of Linguistics, 5(1) pp. 320-331.

Kayam, O., Hirsch, T. (2013). "Socialization of Language through Family Language Policy: A Case Study". (In press).

Kayam, O., Hirsch, T. (2013). "Acculturative Experiences of the English Speaking Immigrants and Repatriates in Israel". (In press).

Kayam, O., Hirsch, T. (2012). "Family Language Policy of the English Speaking Immigrant Community in Israel: Families with Young Children and Their FLP Planning, Management and Outcomes”. International Journal of Linguistics, vol. 4(4), pp. 622-635.

Kayam, O., Hirsch T. (2012). "Family Language Policy of the English Speaking Immigrant Community in Israel: Families with Young Children and their FLP Planning and Management”. International Journal of Linguistics 5(1) pp. 320-331.

Kayam, O., Hirsch, T. (2012). "Using Social Media Networks to Conduct Questionnaire Based Research in Social Studies Case Study: Family Language Policy”. JSR-Journal of Sociological Research, Vol. 3, Issue 2, pp 57-67.

Kayam, O., Hirsch, T., Galily, Y. (2012). "Linguistic Landscape: Investigation of Linguistic Representations of Cape Town”. International Journal of Linguistics. 4:3, 71-77.

Lam, H. (2011). "Raising Children bilingually in Mixed Marriages: Stories of Four Vietnamese-Caucasian Families". ProQuest Dissertations and Theses.

Landry, R., \& Bourhis, R.Y. (1997). "Linguistic landscape and ethnolinguistic vitality: An empirical study". Journal of Language and Social Psychology, 16:1, 23-49.

Paradis, J. (2010). Bilingual Children's Acquisition of English Verb Morphology: Effects of 
Language Exposure, Structure Complexity, and Task Type. Language Learning, 60/3: 651-680.

Portes, A., \& Hao, L. (2002). "The price of uniformity: Language, family, and personality adjustment in the immigrant second generation". Ethnic and Racial Studies, 25, 889-912.

Schecter, S.R., Sharaken-Taboada, D., \& Bayley, R. (1996). Bilingual by choice: Latino parents' rationales and strategies for raising children with two languages. Bilingual Research Journal, 20/2: 261-281.

SchieffAvin, B. B. \& Ochs, E. (1986). Language socialization. Annual Review of Anthropology 15.

Schwartz, M. (2010). "Family Language Policy: Core Issues of an Emerging Field". Applied Linguistics Review. Vol. 1, 171-192, ISSN (Online) May 2010.

Tannenbaum, M. (2003). "The Multifaceted Aspects of Language Maintenance: A new measure for its assessment in immigrant families". International Journal of Bilingual Education 6: 374-393.

Toman, W. (1993). Family Constellation: its effects on personality and social behavior. Springer Publishing Company. 